\title{
Identification of therapeutic target genes with DNA microarray in multiple myeloma cell line treated by IKK $\beta / \mathrm{NF}-\kappa \mathrm{B}$ inhibitor ${ }^{1}$
}

\author{
Aixia Dou', Zhilun Wang', Jingjie Zhao ${ }^{\mathrm{III}}$, Junli Liu ${ }^{\mathrm{IV}}$, Chengyun Zheng ${ }^{\mathrm{V}}$ \\ DOI: http://dx.doi.org/10.1590/S0102-86502014001800001 \\ IPhD, Department of Hematology, Second Hospital of Shandong University, Jinan, Shandong Province, China. Conception and design of the study, \\ acquisition of data, final approval of the version to be published. \\ "MM, Department of Hematology, Second Hospital of Shandong University, Jinan, Shandong Province, China. Conception and design of the study, \\ critical revision. \\ IIIPhD, Department of Hematology, Second Hospital of Shandong University, Jinan, Shandong Province, China. Acquisition, analysis and interpretation \\ of data; critical revision.

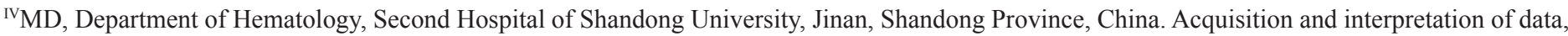 \\ manuscript writing, critical revision. \\ vPhD, Department of Hematology, Second Hospital of Shandong University, Jinan, Shandong Province, China. Manuscript writing, critical revision.
}

\section{ABSTRACT}

PURPOSE: To explore the mechanism of resistance to IKK $\beta$ inhibitor in multiple myeloma (MM) cells and uncover novel therapeutic targets for MM.

METHODS: We downloaded the microarray data (GSE8476) from GEO (Gene Expression Omnibus) database. The data were derived from the human MM cells lines (L363 cells) treated with IKK $\beta$ inhibitor MLN120b (MLN) for eight, 12 and 24 hours. Furthermore, we applied the Search Tool for the Retrieval of Interacting Genes (STRING) and Expression Analysis Systematic Explorer (EASE) database to construct protein-protein interaction networks and identified over-represented pathway among DEGs (differentially expressed genes). RESULTS: We obtained 108 DGEs in $8 \mathrm{~h}$ vs. $12 \mathrm{~h}$ group and 101 ones in $8 \mathrm{~h}$ vs. $24 \mathrm{~h}$ group. Most of DGEs were found to be involved in biological regulation. The significant pathways were Ig A pathway and the CAMs pathways. In addition, 24 common DGEs were found in the networks of the two groups such as ICAM 3 and SELL.

CONCLUSION: Intercellular adhesion molecule 3 and SELL may be potential targets in multiple myeloma treatment in the future. Key words: Multiple Myeloma. Protein Interaction Maps. NF-kappa B. 


\section{Introduction}

Multiple Myeloma (MM), also named plasma cell myeloma, is a malignant tumor of plasma cells, which is characterized by the accumulation of abnormal plasma cells in the bone marrow resulting in the intervention of normal hematopoiesis ${ }^{1}$. MM can result in lesions, hypercalcemia and the production of an abnormal antibody which contributes to various kidney problems ${ }^{1}$. It is reported that 20.000 new cases are diagnosed with MM in United States annually, among which around 10.710 patients died from $\mathrm{MM}^{2,3}$. Besides, there is an increasing trend of $\mathrm{MM}$ incidence in China ${ }^{4}$. MM has posed a great threat to public health globally.

Recently, a growing body of studies were conducted to explore the potential mechanism underlying MM development and uncover the effective therapy ${ }^{5-7}$. Nuclear factor kappa pathway has been reported to play a key role in the progression of MM. Nuclear factor kappa-B (NF-kappa B, NF- $\mathrm{B}$ ), a protein complex, is associated with the DNA transcription, cellular responses to stimuli and immune response to infection ${ }^{8-10}$. As a critical factor, IKK $\beta$

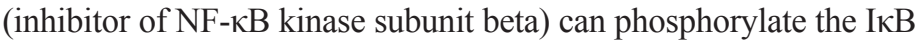
(inhibitor kappa-B) proteins that lead to the polyubiquitination and degradation of $\mathrm{I} \kappa \mathrm{B}$, and finally activate the NF- $\kappa \mathrm{B}$ signaling ${ }^{11}$. The overexpression of NF- $\kappa \mathrm{B}$ can lead to the onset of multiple diseases such as $\mathrm{MM}^{12}$. Many investigations have focused on the inhibition of NF- $\kappa$ B pathways in order to find a targeting therapy for $\mathrm{MM}^{13,14}$. However, the existing mechanism is required depth study.

MLN120b (MLN), served as an IKK $\beta$ inhibitor, can suppress the growth of MM cell lines by mediating the NF- $\kappa B$ pathway ${ }^{15}$. In present study, we applied bioinformatics techniques to analyze the genes expression profiles and gene functions in MM cell line treated by IKK $\beta$ inhibitor MLN. The purpose of this paper was to provide potential targets for MM treatment.

\section{Methods}

Affymetrix microarray and differential expression gene analysis

The gene expression profile dataset GSE8476 was downloaded from GEO (Gene Expression Omnibus) database (http://www.ncbi.nlm.nih.gov/geo/) based on the platform of NCI/ Staudt human $15 \mathrm{~K}$ v13, which was deposited by Annunziata et $a l .{ }^{16}$. The microarray data were derived from the human L363 cells treated with MLN at different time points (8h, 12h, and 24h). There were a total of 8 samples (including 2 samples collected at $8 \mathrm{~h}, 3$ ones at $12 \mathrm{~h}$ and 3 ones at $24 \mathrm{~h}$ ).
The probe-level data were converted into expression measures and the missing data were imputed based on the $\mathrm{K}$ Nearest Neighbors (KNN) method in $\mathrm{R}^{17}$. Then the raw data were normalized using the median method ${ }^{18}$. All the samples were assigned into two groups ( $8 \mathrm{~h}$ vs. $12 \mathrm{~h}$ and $8 \mathrm{~h}$ vs. $24 \mathrm{~h}$ group) for comparison using the samples of $8 \mathrm{~h}$ as reference. The differentially expressed genes (DEGs) in the two groups were identified by limma package in $\mathrm{R}^{19} \cdot \mathrm{p}<0.05$ and $|\log \mathrm{FC}|>1$ were defined as the cutoff value.

\section{Clusters of orthologous groups of proteins classification}

The database of Clusters of Orthologous Groups of proteins (COGs) is a tool for phylogenetic classification of proteins encoded in complete genomes, which currently contains 45350 proteins encoded in 30 complete genomes (http://www. ncbi.nlm. nih. gov/COG) ${ }^{20}$.

All the sequences information of proteins in COG database was firstly downloaded. To investigate the DEGs in functional levels, we performed the protein sequence similarity searches via the basic local alignment search tool BLASTX ${ }^{21}$. The similarity degrees between the sequences of DEGs and COGs were evaluated and $\mathrm{E}$ values $<1 \mathrm{e}-05$ was defined as threshold value.

\section{Pathway enrichment analysis}

Expression Analysis Systematic Explorer (EASE) is a powerful tool for functional analysis of a list of genes ${ }^{22}$. The enriched pathways of DEGs were selected using the Fisher's exact test in EASE and the dysfunctional pathway with $\mathrm{p}<0.05$ was defined as significant.

\section{Construction of protein-protein interaction networks}

Search Tool for the Retrieval of Interacting Genes (STRING) database provides comprehensive information of predicted and experimental interactions of proteins ${ }^{23}$. The DEGs from two groups ( $8 \mathrm{~h}$ vs. $12 \mathrm{~h}$; $8 \mathrm{~h}$ vs. $24 \mathrm{~h}$ ) were mapped into protein-protein interactions based on STRING database. All the associations of proteins were displayed with a confidence score. We selected significant protein pairs with confidence score $>$ 0.7 and constructed the PPI interaction networks by Cytoscape software ${ }^{24}$. 


\section{Results}

\section{Differentially expressed genes analysis}

In order to explore the DEGs in the intervention process of MM, the publicly available microarray dataset GSE8476 was downloaded from GEO. The DEGs with $\mathrm{p}<0.05$ and $|\operatorname{logFC}|>$ 1 were selected for further analysis. Finally, we obtained 209 DEGs including 108 ones in $8 \mathrm{~h}$ vs. $12 \mathrm{~h}$ group and 101 ones in $8 \mathrm{~h}$ vs. $24 \mathrm{~h}$ group.

\section{Clusters of orthologous groups of proteins (COGs) classification analysis}

To investigate the functional change of genes in the intervention process of $\mathrm{MM}$ cell line, we performed COG

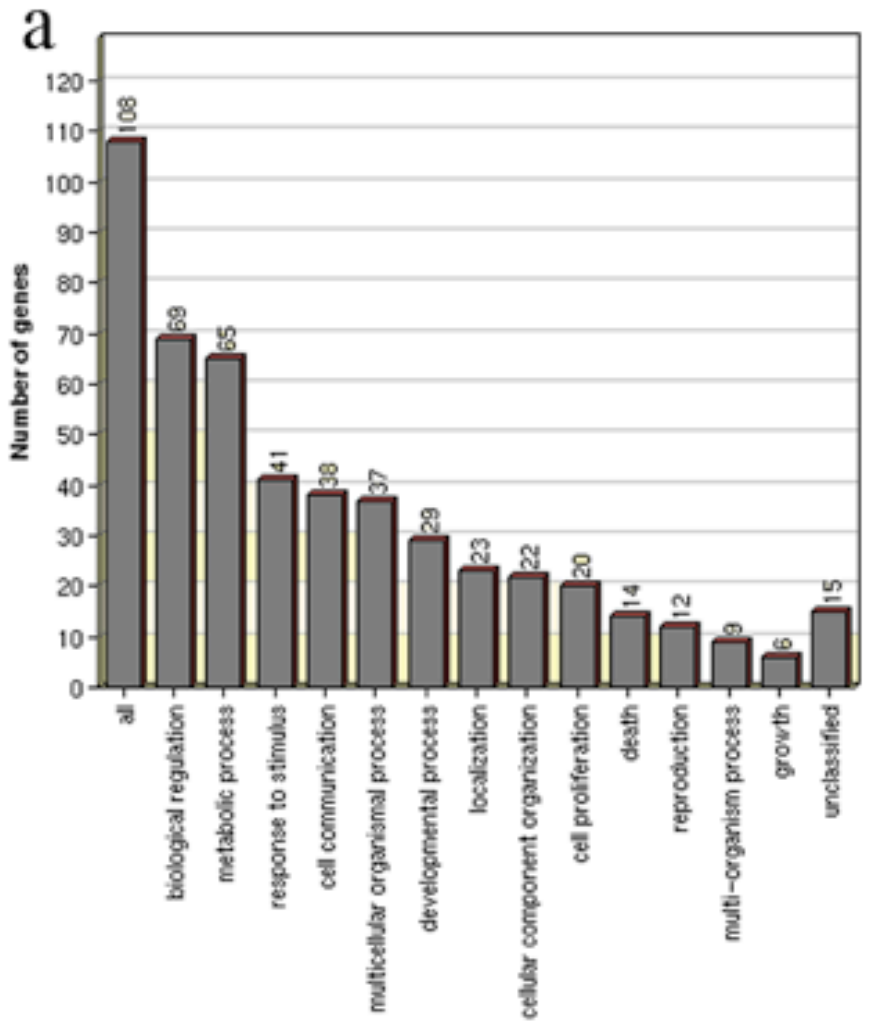

classification analysis. As shown in Figure 1, the DEGs were enriched in 13 different biological processes including biological regulation, metabolic process, stimulus-response, and cell communications. Most of DGEs were found to be involved in biological regulation. The numbers of DGEs involved in various biological processes were similar between $8 \mathrm{~h}$ vs. $12 \mathrm{~h}$ group and $8 \mathrm{~h}$ vs. $24 \mathrm{~h}$ group.

\section{PPI networks}

We established the PPI networks of DEGs from two groups based on the interactions predicted by the STRING database. The networks of DGEs in $8 \mathrm{~h}$ vs. $12 \mathrm{~h}$ group comprised 93 interactions among 64 DEGs, while in $8 \mathrm{~h}$ vs. $24 \mathrm{~h}$ group, there were 105 interactions involved with 58 DEGs (Figure $2 \mathrm{~A}, \mathrm{~B}$ ). In addition, 24 common DGEs were found in the networks of the two groups such as ICAM 3 and SELL (Figure 2 A, B).

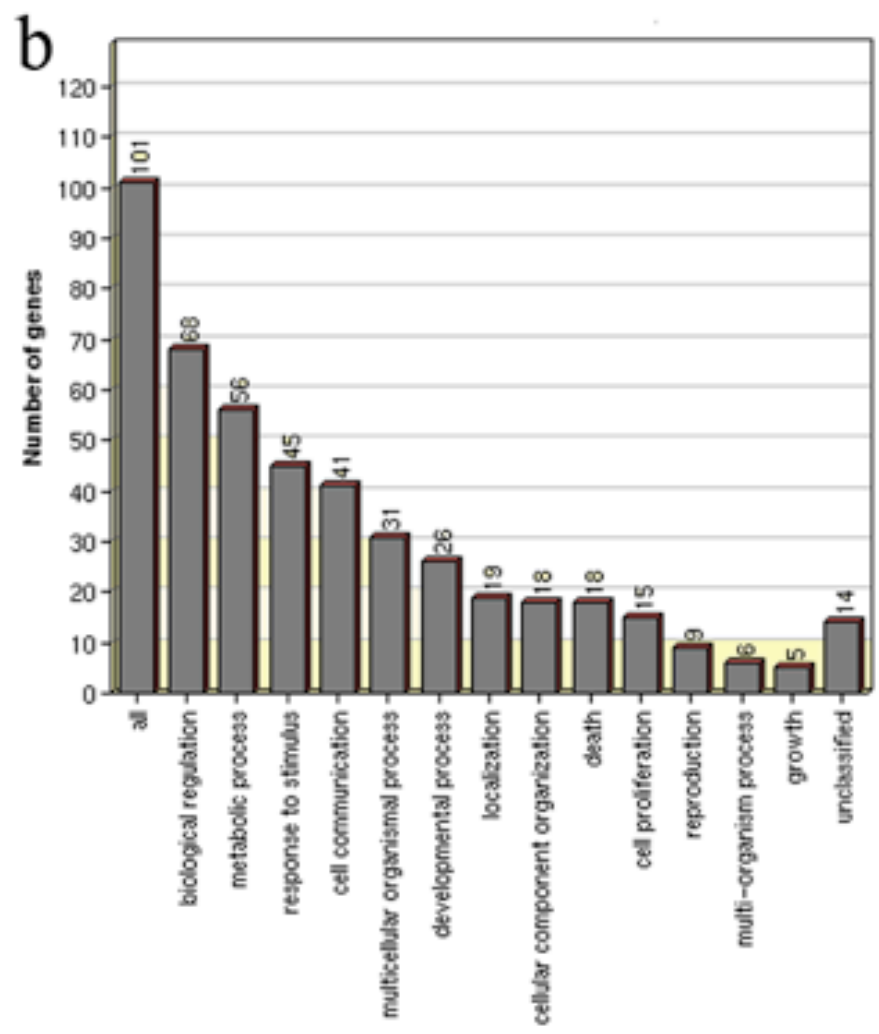

FIGURE 1 - COG classification of DEGs in $8 \mathrm{~h}$ vs. 12h group (A) and $8 \mathrm{~h}$ vs. $24 \mathrm{~h}$ (B). The bar graphs represent the numbers of genes involved in different biological processes. 


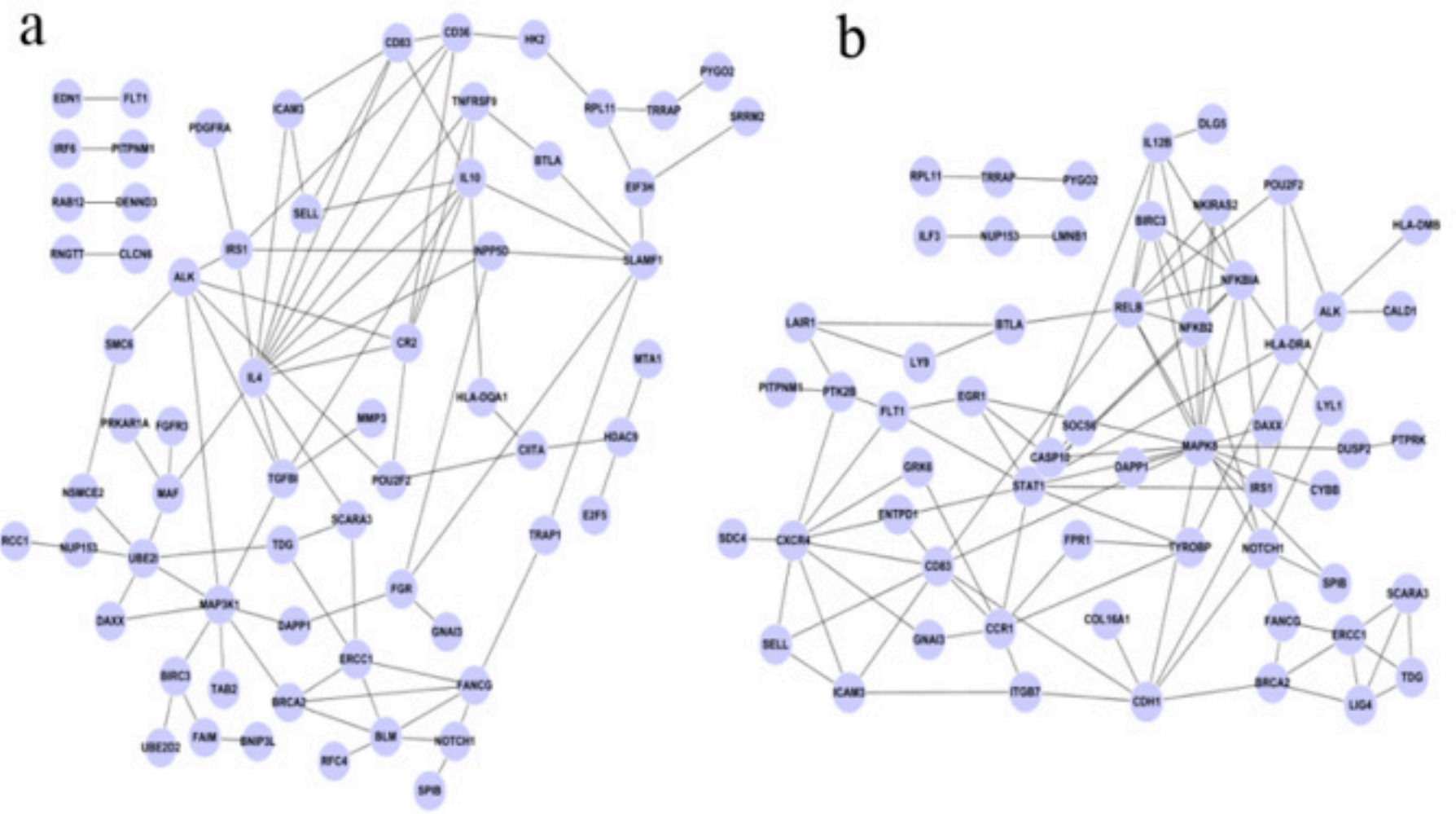

FIGURE 2 - PPI networks of DEGs in $8 \mathrm{~h}$ vs. $12 \mathrm{~h}$ group (A) and $8 \mathrm{~h}$ vs. $24 \mathrm{~h}$ group (B).

\section{Identification of dysfunctional pathway}

The gene-set enrichment analysis was performed by applying EASE. In $8 \mathrm{~h}$ vs. $12 \mathrm{~h}$ group, the significant biological pathways enriched by 64 DEGs were intestinal immune network for IgA (Immunoglobulin A) production and autoimmune thyroid diseases. The pathway of immune network for IgA production was defined as the most significant $(\mathrm{p}<0.04)$ which involved with three DEGs (IL4, Interleukin-4; HLA-DQA1, human leukocyte antigen; IL10, Interleukin-10) (Table 1). In $8 \mathrm{~h}$ vs. $24 \mathrm{~h}$ group, the most significant pathway was cell adhesion molecules (CAMs) pathway $(\mathrm{p}=2.80 \mathrm{E}-04)$ and seven DEGs (ELL: RNA polymerase II elongation factor; ITGB7: integrin $\beta 7$; ICAM3: intercellular adhesion molecule 3; CDH1: Cadherin-1; HLA-DMB: HLA class II histocompatibility

TABLE 1 - The enriched pathways among DEGs in $8 \mathrm{~h}$ vs. $12 \mathrm{~h}$ group.

\begin{tabular}{llccc}
\hline Term & Pathways & Count & PValue & Genes \\
\hline hsa04672 & $\begin{array}{l}\text { Immune } \\
\text { network } \\
\text { for IgA } \\
\text { production }\end{array}$ & 3 & 0.039731139 & IL4, \\
& & & & HLA-DQA1, \\
hsa05320 & $\begin{array}{l}\text { Autoimmune } \\
\text { thyroid }\end{array}$ & 3 & 0.042732582 & IL4, \\
& & & HLA-DQA1, \\
disease & & & IL10 \\
\hline
\end{tabular}

antigen, DM beta chain; SDC4: syndecan-4; and HLA-DRA: HLA class II histocompatibility antigen, DR alpha chain) were enriched in it. Other dysfunctional pathways in $8 \mathrm{~h}$ vs. $24 \mathrm{~h}$ group included immune network for IgA production pathway, cancer involved pathway and toll-like receptor signaling pathway (Table 2).

TABLE 2 - The enriched pathways among DEGs in $8 \mathrm{~h}$ vs. 24h group.

\begin{tabular}{|c|c|c|c|c|}
\hline Term & Pathways & Count & P Value & Genes \\
\hline hsa04514 & $\begin{array}{l}\text { Cell } \\
\text { adhesion } \\
\text { molecules } \\
\text { (CAMs) }\end{array}$ & 7 & $2.80 \mathrm{E}-04$ & $\begin{array}{c}\text { SELL, ITGB7, } \\
\text { ICAM3, CDH1, } \\
\text { HLA-DMB, } \\
\text { SDC4, } \\
\text { HLA-DRA }\end{array}$ \\
\hline hsa04672 & $\begin{array}{l}\text { Immune } \\
\text { network } \\
\text { for IgA } \\
\text { production }\end{array}$ & 4 & 0.004802596 & $\begin{array}{c}\text { CXCR4, ITGB7, } \\
\text { HLA-DMB, } \\
\text { HLA-DRA }\end{array}$ \\
\hline hsa05200 & $\begin{array}{l}\text { Pathways } \\
\text { in cancer }\end{array}$ & 7 & 0.025882116 & $\begin{array}{c}\text { NFKBIA, } \\
\text { BRCA2, CDH1, } \\
\text { MAPK8, } \\
\text { NFKB2, BIRC3, } \\
\text { STAT1 }\end{array}$ \\
\hline hsa04620 & $\begin{array}{l}\text { Toll-like } \\
\text { receptor } \\
\text { signaling } \\
\text { pathway }\end{array}$ & 4 & 0.033818056 & $\begin{array}{c}\text { NFKBIA, } \\
\text { MAPK8, IL12B, } \\
\text { STAT1 }\end{array}$ \\
\hline
\end{tabular}




\section{Discussion}

Multiple Myeloma (MM), a malignant tumor formed by the plasma cells of the bone marrow, is an incurable disease ${ }^{25}$. The role of NF- $\mathrm{KB}$ associated pathways in inhibiting plasma cell apoptosis $^{26}$ is verified by many investigators. IKK plays a crucial role in NF- $\kappa$ B pathway, which is composed of two protein subunits (IKK $\alpha$ and IKK $\beta$ ). Previous reports suggested that IKK $\alpha$ and IKK $\beta$ induced the activation of $N F-\kappa B$, while $N F-\kappa B$ signal transduction pathways were blocked with the absence of IKK $\alpha$ and IKK $\beta^{27}$.

In our work, we downloaded the gene expression data derived from L363 cells (MM cell line) treated by IKK $\beta$ inhibitor MLN120b at different time points to explore the significant DEGs and pathways underlying the mechanism of the resistance of MM cells to MLN. Our results suggested that the most significant pathway was IgA production in immune network in $8 \mathrm{~h}$ vs. $12 \mathrm{~h}$ group and cell adhesion molecules (CAMs) pathway in $8 \mathrm{~h}$ vs. $24 \mathrm{~h}$ group.

IgA plays an essential role in mucosal immunity. The concentration of IgA (secretory immunoglobulin) is correlated with the progression of oral cancer ${ }^{28}$. Monoclonal IgA was determined to be extremely accumulated in the serum of patients with $\mathrm{MM}^{29}$. IL-4 and $I L-10$ were found to be enriched in the pathway of IgA production in immune network. IL-4 and IL-10 are critical regulators in immune responses by activating multiple signaling pathways and affecting the production of $\operatorname{Ig} \mathrm{A}^{30}$. It is reported that IL-4 combined with IL-10 had synergic effect on IgA levels with IgA-deficient (IgAD) patients ${ }^{31}$. The combination of IL-4 and IL-10 have protective effect against lung inflammatory injury $^{32}$. Thus, IgA production is an event in response to MLN and the concentration of $\operatorname{IgA}$ may be biomarker in the treatment process of MM.

Cell adhesion molecules (CAMs) mediated the interactions of cell-cell and cell-substratum such as cell adhesion to adjacent cells and to specific extracellular matrix $(\mathrm{ECM})^{33}$. Cell-cell adhesiveness was reduced in the progression of cancer which contributed to tumor invasion, metastasis and destruction of cell morphogenesis ${ }^{34}$. As outlined in previous study, adhesion molecules played crucial roles in several steps of MM progression ${ }^{35}$. CAMs mediated the MM cells migration and adhesion to bone marrow and triggered the activation of interleukin-6. Many genes were found to be involved in the pathway of cell adhesion such as ITGB7, CDH1, SDC4, ICAM 3 and SELL. The activation of ITGB7 (integrin $\beta 7$ ) was related with cell adhesion, migration and invasion in multiple myeloma (MM) cells. ${ }^{36}$ Silencing of ITGB7 gene blocked MM cells adhesion to extra-cellular matrix and blocked MM cells migration by inhibiting focal adhesion kinase (FAK). The knockdown of ITGB7 suppressed p65-NF-kB (a member of NF- $\kappa B$ family) activity and affected NF- $\kappa B$ involved immune response ${ }^{36}$. The methylation status of $\mathrm{CDH} 1$ and SDC4 promoter was frequently found in the MM progression, which might be potential markers for MM prognosis ${ }^{37,38}$

Besides, ICAM 3 and SELL involved in CAMs pathway were identified to be the common genes in PPI networks of $8 \mathrm{~h}$ vs. $12 \mathrm{~h}$ and $8 \mathrm{~h}$ vs. $24 \mathrm{~h}$ group. ICAM 3 as an intercellular adhesion molecule was found to be overexpressed in the MM progression and mediated cancer cell adhesion to bone stroma ${ }^{35}$. SELL encoded a cell surface adhesion molecule that belongs to the family of adhesion/homing receptors. The encoded molecule contains multiple domains and plays a key role in lymphocyte-endothelial cell interactions ${ }^{39}$. The single-nucleotide polymorphisms in this gene have been associated with various diseases, such as immunoglobulin A nephropathy. Although reports concerning the role of SELL in MM were rare, ICAM 3 and SELL were critical targets in MM cells intervention by MLN. In conclusion, during the treatment with MLN120b, several pathways were significantly changed in L363 cells, among which the most important ones were Ig A pathway and the CAMs pathways. In our investigation, the comprehensive bioinformatics analysis provided a novel viewpoint to understand the pathophysiology of MM progression.

\section{Conclusion}

Intercellular adhesion molecule 3 and SELL may be potential targets in multiple myeloma treatment in the future.

\section{References}

1. Raab MS, Podar K, Breitkreutz I, Richardson PG, Anderson KC. Multiple myeloma. Lancet. 2009 Jul 25;374(9686):324-39. doi: 10.1016/S0140-6736(09)60221-X.

2. Pingali SR, Haddad RY, Saad A. Current concepts of clinical management of multiple myeloma. Dis Mon. 2012 Apr;58(4):195207. doi: 10.1016/j.disamonth. 2012.01.006.

3. Dunn JD, Huff CA, Mullins CD, Bugos KG. Oncology pharmacy management and the evolving role of managed care: recommendations for a changing environment with a focus on multiple myeloma. J Manag Care Pharm. 2012 Oct;18(8-a):S3-29.

4. Tao Z-f, Fu W-j, Yuan Z-g, Wang D-x, Chen Y-b, Hou J. Prognostic factors and staging systems of multiple myeloma: a single centre study in China. Chin Med J (Engl). 2007 Oct;120(19): 1655. PMID: 17935664.

5. Bardeleben C, Sharma S, Reeve JR, Bassilian S, Frost PJ, Hoang B, Shi Y, Lichtenstein A. Metabolomics identifies pyrimidine starvation as the mechanism of 5-aminoimidazole-4-carboxamide1 - $\beta$-riboside (AICAr) induced apoptosis in multiple myeloma cells. Mol Cancer Ther. 2013. Jul;12(7):1310-21. doi: 10.1158/15357163.MCT-12-1042. 
6. Hideshima T, Anderson KC. Molecular mechanisms of novel therapeutic approaches for multiple myeloma. Nat Rev Cancer. 2002 Dec;2(12): 927-37. PMID: 12459731.

7. Alsayed Y, Ngo H, Runnels J, Leleu X, Singha UK, Pitsillides CM, Spencer JA, Kimlinger T, Ghobrial JM, Jia X. Mechanisms of regulation of CXCR4/SDF-1 (CXCL12)-dependent migration and homing in multiple myeloma. Blood. 2007 Apr;109(7):2708-17. PMID: 17119115.

8. Brasier AR. The NF- $\mathrm{kB}$ regulatory network. Cardiovasc Toxicol. 2006;6(2):111-30. PMID: 17303919.

9. Perkins ND. Integrating cell-signalling pathways with NF- $\mathrm{BB}$ and IKK function. Nat Rev Mol Cell Biol. 2007 Jan;8(1):49-62. PMID: 17183360

10. Gilmore $\mathrm{T}$. The Rel/NF- $\kappa \mathrm{B} / \mathrm{I} \kappa \mathrm{B}$ signal transduction pathway and cancer. Signal Transduction Cancer. 2003 Oct3;13(7):1367-78. doi: 10.1007/0-306-48158-8_10.

11. Cheon JH, Kim JS, Kim JM, Kim N, Jung HC, Song IS. Plant sterol guggulsterone inhibits nuclear factor $\square \kappa \mathrm{B}$ signaling in intestinal epithelial cells by blocking I $\mathrm{KB}$ kinase and ameliorates acute murine colitis. Inflamm Bowel Dis. 2006 Dec;12(12):1152-61. PMID: 17119390 .

12. Chauhan D, Uchiyama H, Akbarali Y, Urashima M, Yamamoto K-1, Libermann T, Anderson K. Multiple myeloma cell adhesion-induced interleukin-6 expression in bone marrow stromal cells involves activation of NF-kappa B. Blood. 1996 Feb;87(3):1104-12. PMID: 8562936.

13. YinJun L, Jie J, YunGui W. Triptolide inhibits transcription factor NF-kappaB and induces apoptosis of multiple myeloma cells. Leuk Res. 2005 Jan;29(1):99-105. PMID: 15541481.

14. Keats JJ, Fonseca R, Chesi M, Schop R, Baker A, Chng W-J, Van Wier S, Tiedemann R, Shi C-X, Sebag M. Promiscuous mutations activate the noncanonical NF- $\mathrm{kB}$ pathway in multiple myeloma. Cancer Cell. 2007 Aug;12(2):131-44. PMID: 17692805.

15. Annunziata CM, Davis RE, Demchenko Y, Bellamy W, Gabrea A, Zhan F, Lenz G, Hanamura I, Wright G, Xiao W. Frequent engagement of the classical and alternative NF- $\mathrm{kB}$ pathways by diverse genetic abnormalities in multiple myeloma. Cancer Cell. 2007 Aug;12(2):115-30. PMID: 17692804.

16. Annunziata CM, Davis RE, Demchenko Y, Bellamy W, Gabrea A, Zhan F, Lenz G, Hanamura I, Wright G, Xiao W, Dave S, Hurt EM, Tan B, Zhao H, Stephens O, Santra M, Williams DR, Dang L, Barlogie B, Shaughnessy JD, Jr., Kuehl WM, Staudt LM. Frequent engagement of the classical and alternative NF-kappaB pathways by diverse genetic abnormalities in multiple myeloma. Cancer Cell. 2007 Aug;12(2):115-30. doi: 10.1016/j.ccr.2007.07.004.

17. Troyanskaya O, Cantor M, Sherlock G, Brown P, Hastie T, Tibshirani R, Botstein D, Altman RB. Missing value estimation methods for DNA microarrays. Bioinformatics. 2001 Jun;17(6):520-5. PMID: 11395428

18. Fujita A, Sato J,R Rodrigues L de O, Ferreira CE, Sogayar MC. Evaluating different methods of microarray data normalization. BMC Bioinformatics. 2006 Oct; 7:469. PMID: 17059609.

19. Smyth GK. Limma: linear models for microarray data, bioinformatics and computational biology solutions using $\mathrm{R}$ and Bioconductor. Springer: 2005. p. 397-420. 10.1007/0-387-29362-0 23

20. Tatusov RL, Natale DA, Garkavtsev IV, Tatusova TA, Shankavaram UT, Rao BS, Kiryutin B, Galperin MY, Fedorova ND, Koonin EV. The COG database: new developments in phylogenetic classification of proteins from complete genomes. Nucleic Acids Res. 2001 Jan;29(1):22-8. PMID: 11125040.

21. AltschuP SF, Gish W, Miller W, Myers EW, Lipman DJ. Basic local alignment search tool. J Mol Biol. 1990 Oct;215(3):403-10. PMID: 2231712 .
22. Hosack DA, Dennis Jr G, Sherman BT, Lane HC, Lempicki RA. Identifying biological themes within lists of genes with EASE. Genome Biol. 2003 Sep;4(10):R70. PMID: 14519205.

23. Szklarczyk D, Franceschini A, Kuhn M, Simonovic M, Roth A, Minguez P, Doerks T, Stark M, Muller J, Bork P. The STRING database in 2011: functional interaction networks of proteins, globally integrated and scored. Nucleic Acids Res. 2011 Jan;39(Database issue):D561-8. doi: 10.1093/nar/gkq973 .

24. Shannon P, Markiel A, Ozier O, Baliga NS, Wang JT, Ramage D, Amin N, Schwikowski B, Ideker T. Cytoscape: a software environment for integrated models of biomolecular interaction networks. Genome Res. 2003 Nov;13(11):2498-504. PMID: 14597658.

25. Gahrton G. Multiple myeloma - a curable disease? J Intern Med. 1992 May;231(5): 449-52. PMID: 1602281.

26. Mitsiades N, Mitsiades CS, Poulaki V, Chauhan D, Richardson PG, Hideshima T, Munshi NC, Treon SP, Anderson KC. Apoptotic signaling induced by immunomodulatory thalidomide analogs in human multiple myeloma cells: therapeutic implications. Blood. 2002 Jun;99(12):4525-30. PMID: 12036884.

27. Thomas RK, Re D, Wolf J, Diehl V. Part I: Hodgkin's lymphomamolecular biology of Hodgkin and Reed-Sternberg cells. Lancet Oncol. 2004 Jan;5(1):11-8. PMID: 14700604.

28. Brown AM, Lally ET, Frankel A, Harwick R, Davis LW, Rominger CJ. The association of the IgA levels of serum and whole saliva with the progression of oral cancer. Cancer. 1975 Apr;35(4):115462. PMID: 803867.

29. Plaut AG. The IgA1 proteases of pathogenic bacteria. Annu Rev Microbiol. 1983;37(1):603-22. PMID: 6416146.

30. Kaplan MH, Schindler U, Smiley ST, Grusby MJ. Stat6 is required for mediating responses to IL-4 and for the development of Th2 cells. Immunity. 1996 Mar;4(3):313-9. PMID: 8624821.

31. Marconi M, Plebani A, Avanzini M, Maccario R, Pistorio A, Duse M, Stringa M, Monafo V. IL-10 and IL-4 co-operate to normalize in vitro IgA production in IgA-deficient (IgAD) patients. Clin Exp Immunol. 1998 Jun;112(3):528-32. PMID: 9649225.

32. Mulligan M, Jones M, Vaporciyan A, Howard M, Ward P. Protective effects of IL-4 and IL-10 against immune complex-induced lung injury. J Immunol. 1993 Nov;151(10):5666-74. PMID: 7901280.

33. Albelda SM, Buck CA. Integrins and other cell adhesion molecules. FASEB J. 1990 Aug;4(11):2868-80. PMID: 2199285.

34. Hirohashi S, Kanai Y. Cell adhesion system and human cancer morphogenesis. Cancer Sci. 2003 Jul;94(7):575-81. PMID: 12841864.

35. Teoh G, Anderson KC. Interaction of tumor and host cells with adhesion and extracellular matrix molecules in the development of multiple myeloma. Hematol Oncol Clin North Am. 1997 Feb;11(1):27-42. PMID: 9081202.

36. Neri P, Ren L, Azab AK, Brentnall M, Gratton K, Klimowicz AC, Lin $C$, Duggan $P$, Tassone $P$, Mansoor A. Integrin $\beta 7$-mediated regulation of multiple myeloma cell adhesion, migration, and invasion. Blood. 2011 Jun 9;117(23):6202-13. doi: 10.1182/blood-2010-06-292243.

37. de Carvalho F, Colleoni GW, Sampaio Almeida MS, Carvalho AL, Vettore AL. TGF $\beta$ R2 aberrant methylation is a potential prognostic marker and therapeutic target in multiple myeloma. Int J Cancer. 2009 Oct 15;125(8):1985-91. doi: 10.1002/ijc.24431.

38. Ekmekci CG, Gutiérrez MI, Siraj AK, Ozbek U, Bhatia K. Aberrant methylation of multiple tumor suppressor genes in acute myeloid leukemia. Am J Hematol. 2004 Nov;77(3): 33-40. PMID: 15495254.

39. Newman WG, Clayton $\square$ Smith J, Metcalfe K, Cole R, Tartaglia M, Brancati F, Morara S, Novelli A, Liu X, Siminovitch KA. Geroderma osteodysplastica maps to a $4 \mathrm{Mb}$ locus on chromosome 1q24. Am J Med Genet A. 2008 Dec 1;146A(23):3034-7. doi: 10.1002/ ajmg.a.32564. 
Dou A et al.

\section{Correspondence:}

Chengyun Zheng

Department of Hematology, Second Hospital of Shandong University

No. 247, Beiyuan Da Jie, Jinan

Shandong Province, China, 250033

Phone/Fax: +86-0531-85875634

douax0110@163.com

Received: June 19, 2014

Review: Aug 18, 2014

Accepted: Sep 22, 2014

Conflict of interest: none

Financial source: Seed Fund of the 2nd Hospital of Shandong University

${ }^{1}$ Research performed at Department of Hematology, Second Hospital of Shandong University, Jinan, China. 